\title{
Effect of Insulin Resistance on Lipolytic activity of Adipose Tissue in Male Rats
}

\author{
Eldeeb $R,,^{*}$ Gamal-Eldin $M H,{ }^{2}$ Khowailed EA, ${ }^{2}$ Fathy $M M,{ }^{2}$ Shantakumari $N,{ }^{1}$ Saleh $M E^{3}$
}

${ }^{1}$ Department of Physiology, Gulf Medical University (GMU) Ajman, UAE, ${ }^{2}$ Department of Physiology, college of medicine, Cairo University, Egypt, ${ }^{3}$ Chemical and clinical pathology department, Faculty of Medicine, Cairo University, Egypt

\begin{abstract}
Background: The excess usage of fructose as a sweetener has raised the incidence of insulin resistance among the population which is associated with dyslipedemia, hypertension and obesity. This work studied the effect of induced insulin resistance on body weight, blood pressure, lipid profile, glycemic state and lipolytic activity of adipose tissue in male rats.
\end{abstract}

Methods: Twenty male rats of $129.4 \mathrm{~g}$ average body weight (BW) were divided equally into two groups. Both had free access to water. The control group had pure water; the experimental group had water mixed with $25 \%$ of fructose to induce insulin resistance. After 3 months body weight, blood pressure, fasting blood glucose, insulin levels, lipid profile of both groups were measured and lipolytic activity of adipose tissue was assessed.

Results: Rats given fructose for 3 months showed significant increase in BW, systolic blood pressure, triglyceride, Cholesterol, low density lipoprotein, fasting blood glucose and insulin levels with a significant decline in highdensity lipoprotein. Lipolytic activity of subcutaneous (SC) and visceral adipose tissue in presence of adrenaline increased significantly which runs in parallel with the results obtained in presence of insulin as it showed a significant rise in both SC and visceral adipose tissue. Data were considered statistically significant at alpha level of 5\%.

Dr. Rasha Eldeeb

Assistant Professor, Department of Physiology

College of Medicine, Gulf Medical University

Ajman, UAE

PO Box: 4184

Email: dr.rasha@gmu.ac.ae

\section{Citation}

Eldeeb R, Gamal-Eldin MH, Khowailed EA, Fathy MM, Shantakumari N, Saleh ME. Effect of Insulin Resistance on Lipolytic activity of Adipose Tissue in Male Rats. Nepal Journal of Medical sciences 2012;1(2): 68-73.

Conclusion: Insulin resistance induced in male rat by high fructose consumption showed a significant rise in BW and is associated with hypertension and dyslipidemia with significant rise in lipolytic activity of both SC and visceral adipose tissue.

Keywords: Insulin resistance; adipose tissue; fructose; hypertension

\section{Background:}

Many health problems are caused by excessive intake of carbohydrates which have become frequent among populations of developed and emerging countries. ${ }^{1}$ Common sources of carbohydrates include sugars in soft drinks such as sucrose, fructose and glucose from hydrolyzed corn. ${ }^{2}$

Several studies using animal models have indicated that fructose is responsible for the increased incidence of diabetes and cardio-kidney diseases., ${ }^{3,4}$ Adding small amounts of fructose to foods and drinks increases the hepatic synthesis of glycogen in humans and reduces the glycemic response in subjects with Type 2 diabetes mellitus, signifying the importance of fructose in liver metabolism. Large amounts of fructose provide an irregular source of precursors of carbon to affect hepatic lipogenesis. ${ }^{5}$ 
Regional variations in adipose tissue function seem to have an additional bearing on insulin resistance. Visceral fat accumulation has a stronger association with insulin resistance than subcutaneous fat accumulation. This has in part been attributed to higher lipolytic activity in visceral than subcutaneous adipose tissue. ${ }^{6}$

The purpose of this study was to detect the effect of induced insulin resistance by ingestion of fructose on the body weight, systolic blood pressure, lipid profile, glycemic state and lipolytic activity of adipose tissue in both subcutaneous and visceral adipose tissue.

\section{Methods:}

The Experimental Research Committee of the Physiology Department and the ethics committee of College of Medicine Cairo University approved all procedures. Male rats were supplied by Animal Care facility of Cairo University. The study was conducted in accordance with World Helsinki declaration.

Rats of the same average weight were divided into two groups of 10 rats each, both groups were fed commercial rat chow; control group (C gp) had free access to pure water. Fructose group ( $\mathrm{F} \mathrm{gp}$ ) had free access to sweetened water with $25 \%$ fructose to induce insulin resistance. Both groups were maintained in a room at $23^{\circ} \mathrm{C}$ with light on from 7:00 till 18:00. After 3 months the body weight, blood pressure, fasting blood glucose and insulin, serum triglyceride (TG), high density lipoprotein (HDL), low density lipoprotein (LDL) and total cholesterol levels were measured, Lipolytic activity as well as the antilipolytic activity of insulin for both visceral and subcutaneous adipose tissue were measured.

Both groups ( $\mathrm{C}$ gp and $\mathrm{F}$ gp) were offered a commercial rat chow consisting of (w/w) Crude protein $22 \%$, Crude fat $4 \%$, Crude carbohydrate $38 \%$, Crude fibers $5 \%$ ash $8 \%$ and added minerals $3 \%$. Food was given fresh each day; rats ate a varying amount of 15-30 grams/day and had a free access to water. Systolic blood pressure in rats was measured by Harvard rat tail blood pressure monitor system.

Rats were killed by decapitation; the study was performed on subcutaneous adipose tissue and visceral (omental) adipose tissue. One gram samples taken from each group were immediately transported to the laboratory in Ringer's solution at room temperature and digested by Rodbell methods. ${ }^{7,8}$ The suspension of cells was centrifuged for one minute at $4000 \mathrm{rpm}$. The fat cells floated to the surface and the stromal-vascular cells were sedimented. Fifty $\mu l$ of adrenaline $(1 \mathrm{mg} / \mathrm{ml})$ was added to $0.5 \mathrm{ml}$ supernatant and incubated for 30 minute at $37^{\circ} \mathrm{C}$, another $0.5 \mathrm{ml}$ supernatant was mixed with $50 \mu \mathrm{l}$ of adrenaline $(1 \mathrm{mg} / \mathrm{ml})$ and incubated for 30 minute at $37^{\circ} \mathrm{C}$ followed by adding $50 \mu \mathrm{l}$ of act rapid insulin $(100 \mathrm{U} / \mathrm{ml})$ to it and incubated for another 30 minutes at $37^{\circ} \mathrm{C}$. Lipolytic activity was determined by measuring free glycerol released from fat cells by (Colorimetric kits DIALAB Co.) for each set.

All serum variables were performed on samples taken from overnight unfed rats. Blood glucose was measured by glucose oxidase method (kit510-A, Sigma), ${ }^{9}$ Insulin level was assessed by ELISA Kit purchased from (DRG Company). Serum triglycerides were measured by lipoprotein lipase technique (Colorimetric triglyceride kits DIALAB Co.) Total serum cholesterol (esterified and free forms) by (Colorimetric Cholesterol kit (352-20, Sigma). ${ }^{10}$ HDL-C was measured by Colorimetric method with (Stanbio kit No. 0599) ${ }^{10}$ LDL-C serum level was calculated by using the following equation: ${ }^{10,11}$

$$
\mathrm{LDL}-\mathrm{C}=\mathrm{TC}-\frac{(\mathrm{HDL}-\mathrm{C}+\mathrm{TG})}{5}
$$

Fructose, Bovine serum albumin (BSA; A 6003, essentially fatty acid-free, Sigma), collagenase IV (Sigma Co.), adrenalin (Sigma), Insulin (EIL LILLY Co.) and a buffer containing the following (in $\mathrm{mM}$ ): $137 \mathrm{NaCl}, 5 \mathrm{KCl}, 4.2$ $\mathrm{NaHCO} 3,1.3 \mathrm{CaCl} 2,0.5 \mathrm{MgCl} 2,0.5 \mathrm{KH} 2 \mathrm{PO} 4,0.5 \mathrm{MgSO} 4$, 20 HEPES ( $\mathrm{pH} 7.4$ ), and 1\% BSA., the above mentioned buffer was supplemented with $5 \mathrm{mM}$ glucose.

Results are expressed as mean values with their standard deviation. The Student's t test was used to compare the two groups. Significance was set at $\mathrm{P}<0.05$ level.

\section{Results:}

Body weight (BW) changes table (1):

Rats in (C gp) weighed $192.4 \pm 8.11$ g. In ( $\mathrm{F}$ gp) BW increased to $247.7 \pm 49.66 \mathrm{~g}$ showing a significant increase by $28.7 \%$ compared to ( $\mathrm{C} \mathrm{gp}$ ).

Table 1: Effect of induced insulin resistance (F gp) on Body Weight and Systolic Blood Pressure

\begin{tabular}{lcccc}
\hline & \multicolumn{2}{c}{ C gp } & \multicolumn{2}{c}{ F gp } \\
& $\begin{array}{c}\text { Body } \\
\text { weight } \\
(\mathrm{BW})(\mathrm{g})\end{array}$ & $\begin{array}{c}\text { Systolic } \\
\text { Blood } \\
\text { pressure } \\
(\mathrm{mmHg})\end{array}$ & $\begin{array}{c}\text { Body } \\
\text { weight } \\
(\mathrm{BW})(\mathrm{g})\end{array}$ & $\begin{array}{c}\text { Systolic } \\
\text { Blood } \\
\text { pressure } \\
(\mathrm{mmHg})\end{array}$ \\
\hline Mean & 192.4 & 121 & 247.7 & 137.9 \\
\pm SD & 8.11 & 6.51 & 49.66 & 9.57 \\
\% Change & & & $28.7 \% \%^{\mathrm{a}}$ & $13.9 \%^{\mathrm{a}}$ \\
P value & & & $<0.05^{\mathrm{a}}$ & $<0.05^{\mathrm{a}}$ \\
\hline
\end{tabular}

${ }^{a}$ compared to $(\mathrm{C} g \mathrm{p})$ 


\section{Systolic arterial blood pressure (BP):}

Systolic BP in (C gp) was $121 \pm 6.51 \mathrm{mmHg}$; it increases to $137.9 \pm 9.57 \mathrm{mmHg}$ in (F gp) showing a significant increase by $13.9 \%$ relative to $(\mathrm{C} \mathrm{gp})$.

\section{Lipid profile:}

Table 2: Effect of induced insulin resistance (Fgp) on (Cholesterol, TG, HDL and LDL) in mg/dl

\begin{tabular}{|c|c|c|c|c|c|c|c|c|}
\hline & \multicolumn{4}{|c|}{ C gp } & \multicolumn{4}{|c|}{ F gp } \\
\hline & $\mathrm{TG}$ & $\begin{array}{l}\text { chole- } \\
\text { sterol }\end{array}$ & HDL & LDL & TG & $\begin{array}{l}\text { chole- } \\
\text { sterol }\end{array}$ & HDL & LDL \\
\hline Mean & 54.1 & 84.7 & 30.1 & 43.6 & 66.7 & 87.4 & 28.3 & 46.1 \\
\hline$\pm \mathrm{SD}$ & \pm 8.87 & \pm 4.76 & \pm 1.91 & \pm 2.80 & \pm 6.51 & \pm 3.25 & \pm 1.76 & \pm 2.32 \\
\hline$\%$ & & & & & $23.2 \% \mathrm{a}^{\mathrm{a}}$ & $3 \%{ }^{a}$ & $5.9 \% \%^{\mathrm{a}}$ & $5.6 \%{ }^{\mathrm{a}}$ \\
\hline Change & & & & & & & & \\
\hline $\mathrm{P}$ & & & & & $<0.05^{\mathrm{a}}$ & $<0.05^{\mathrm{a}}$ & $<0.05^{\mathrm{a}}$ & $<0.05^{\mathrm{a}}$ \\
\hline
\end{tabular}

${ }^{a}$ compared to (C gp)

Triglyceride level in (C gp) was $54.1 \pm 8.87 \mathrm{mg} / \mathrm{dl}$. It increased to $66.7 \pm 6.51 \mathrm{mg} / \mathrm{dl}$ in (F gp) showing a significant increase by $23.2 \%$ compared to (C gp)

Cholesterol level in (C gp) was $84.7 \pm 4.76 \mathrm{mg} / \mathrm{dl}$. It increased to $87.4 \pm 3.25 \mathrm{mg} / \mathrm{dl}$ in (F gp) showing a significant rise by $3 \%$ compared to $(\mathrm{C} \mathrm{gp})$.

HDL and LDL were $30.1 \pm 1.91 \mathrm{mg} / \mathrm{dl}$ and $43.6 \pm 2.80$ $\mathrm{mg} / \mathrm{dl}$ respectively in ( $\mathrm{C} \mathrm{gp}$ ). In ( $\mathrm{F} \mathrm{gp}$ ) HDL significantly decreased by $5.9 \%$ compared to $(\mathrm{C} \mathrm{gp})$ being $28.3 \pm 1.76$ $\mathrm{mg} / \mathrm{dl}$.

While LDL level significantly increased by $5.6 \%$ compared to $(\mathrm{C}$ gp) being $46.1 \pm 2.32 \mathrm{mg} / \mathrm{dl}$.

Fasting blood glucose and Insulin levels :

Table 3: Effect of induced insulin resistance (F gp) on blood level of glucose (mg/dl) and insulin (ug/l)

\begin{tabular}{ccccc} 
& \multicolumn{2}{c}{ C gp } & \multicolumn{2}{c}{ F gp } \\
& $\begin{array}{c}\text { Glucose } \\
(\mathrm{mg} / \mathrm{dl})\end{array}$ & $\begin{array}{c}\text { Insulin } \\
(\mathrm{ug} / \mathrm{l})\end{array}$ & $\begin{array}{c}\text { Glucose } \\
(\mathrm{mg} / \mathrm{dl})\end{array}$ & $\begin{array}{c}\text { Insulin } \\
(\mathrm{ug} / \mathrm{l})\end{array}$ \\
\hline Mean & 76.8 & 0.1 & 165.5 & 0.5 \\
\pm SD & 6.39 & 0.08 & 12.57 & 0.32 \\
\% Change & & & $115.4 \%^{\mathrm{a}}$ & $232.8 \%^{\mathrm{a}}$ \\
P & & & $<0.05^{\mathrm{a}}$ & $<0.05^{\mathrm{a}}$ \\
\hline
\end{tabular}

${ }^{\mathrm{a}}$ compared to $(\mathrm{Cgp})$

Blood glucose level was $76.8 \pm 6.39 \mathrm{mg} / \mathrm{dl}$ in $(\mathrm{C}$ gp $)$ versus
$165.5 \pm 12.57 \mathrm{mg} / \mathrm{dl}$ in (F gp) showing a significant increase in $(\mathrm{F} g \mathrm{gp})$ by $115.4 \%$, relative to $(\mathrm{C} \mathrm{gp})$.

In parallel with changes in blood glucose level, insulin level was $0.1 \pm 0.08 \mathrm{u} / 1$ in $(\mathrm{C}$ gp) versus $0.5 \pm 0.32 \mathrm{ug} / 1$ in $(\mathrm{F}$ gp), showing a significant increase by $232.8 \%$ in ( $\mathrm{F}$ gp) compared to (C gp).

\section{Lipolytic activity of subcutaneous (SC) adipose tissue:}

Table 4: Effect of induced insulin resistant (F gp) on Lipolytic activity and anti-lipolytic activity of in subcutaneous (SC) and visceral adipose tissue; (measured by the amount of free glycerol released in $\mathrm{mg}$ / dl in presence of adrenalin)

\begin{tabular}{|c|c|c|c|c|c|c|c|c|}
\hline & \multicolumn{2}{|c|}{ C gp (adrenalin) } & \multicolumn{2}{|c|}{ F gp (adrenalin) } & \multicolumn{2}{|c|}{ C gp (insulin) } & \multicolumn{2}{|c|}{ F gp (insulin) } \\
\hline & $\mathrm{Sc}$ & Visceral & $\mathrm{Sc}$ & Visceral & $\mathrm{Sc}$ & Visceral & $\mathrm{Sc}$ & Visceral \\
\hline Mean & 176.6 & 210.0 & 274.2 & 375.1 & 11.0 & 27.0 & 23.1 & 72.2 \\
\hline$\pm \mathrm{SD}$ & 43.35 & 54.12 & 40.09 & 20.14 & 4.42 & 6.56 & 8.06 & 23.49 \\
\hline$\%$ Change & & & $55.2 \%{ }^{\mathrm{a}}$ & $78.6 \%^{\mathrm{a}}$ & & & $109.3 \%{ }^{\mathrm{a}}$ & $167.1 \%^{\mathrm{a}}$ \\
\hline$P$ & & & $<0.05^{\mathrm{a}}$ & $<0.05^{\mathrm{a}}$ & & & $<0.05^{\mathrm{a}}$ & $<0.05^{\mathrm{a}}$ \\
\hline
\end{tabular}

${ }^{a}$ compared to $(\mathrm{Cgp})$

Lipolytic activity of SC tissue in presence of adrenaline was $176.6 \pm 43.36 \mathrm{mg} / \mathrm{dl}$ in (C gp) versus $274.2 \pm 40.09 \mathrm{mg} / \mathrm{dl}$ in (F gp) showing a significant increase by $55.2 \%$ in $(\mathrm{F} \mathrm{gp})$ relative to $(\mathrm{C} \mathrm{gp})$,

In addition, the lipolytic activity of SC tissue in presence of insulin was $11.0 \pm 4.42 \mathrm{mg} / \mathrm{dl}$ in $(\mathrm{C}$ gp) versus $23.1 \pm 8.06$ $\mathrm{mg} / \mathrm{dl}$ in (F gp) showing a significant increase by $109.3 \%$ in (F gp) compared to ( $\mathrm{C} \mathrm{gp}$ ).

\section{Lipolytic activity of visceral adipose tissue}

Lipolytic activity of visceral adipose tissue in presence of adrenaline was $210.0 \pm 45.12 \mathrm{mg} / \mathrm{dl}$ in (C gp) versus $375.1 \pm$ $20.14 \mathrm{mg} / \mathrm{dl}$ in (Fgp), showing a significant increase by 78.6 $\%$ in (F gp) compared to (C gp).

The lipolytic activity of visceral adipose tissue in presence of insulin was $27.0 \pm 6.65 \mathrm{mg} / \mathrm{dl}$ in (C gp) versus $72.2 \pm$ $23.49 \mathrm{mg} / \mathrm{dl}$ in (F gp). It significantly increased by $167.1 \%$ in ( $\mathrm{F} \mathrm{gp}$ ) compared to (C gp).

In addition in presence of adrenalin the lipolytic activity of visceral adipose tissue was significantly higher than of $\mathrm{SC}$ adipose tissue; In (C gp) it was $210.0 \pm 54.12 \mathrm{mg} / \mathrm{dl}$ in visceral adipose tissue versus $176.6 \pm 43.36 \mathrm{mg} / \mathrm{dl}$ in $\mathrm{SC}$ and in ( $\mathrm{F} \mathrm{gp}$ ) it was $375.1 \pm 20.14 \mathrm{mg} / \mathrm{dl}$ in visceral adipose tissue versus $274.2 \pm 40.09 \mathrm{mg} / \mathrm{dl}$ in SC adipose tissue. 
Also, in presence of insulin the lipolytic activity of visceral adipose tissue was significantly higher than SC adipose tissue; In (C gp) it was $27.0 \pm 6.65 \mathrm{mg} / \mathrm{dl}$ in visceral adipose tissue versus $11.0 \pm 4.42 \mathrm{mg} / \mathrm{dl}$ in SC adipose tissue and in (F gp) it was $72.2 \pm 23.49 \mathrm{mg} / \mathrm{dl}$ in visceral adipose tissue versus $23.1 \pm 8.06 \mathrm{mg} / \mathrm{dl}$ in $\mathrm{SC}$ adipose tissue.

\section{Discussion:}

\section{Effect of insulin resistance on the studied parameters:}

Insulin resistance in rats was induced by adding $25 \%$ of fructose to their drinking water. Results revealed significant increase in $\mathrm{BW}$ of insulin resistant rats by $28.7 \%$, in accordance with studies saying that energy intake, body weight, and adiposity all increase in animals consuming high-fructose diets, as fructose does not stimulate insulin secretion from pancreatic $\beta$ cells due to the low concentrations of the fructose transporter GLUT5 in B cells, suggesting that chronic fructose consumption causes leptin resistance, which promote the development of obesity in response to a high fat diet. ${ }^{13,14}$

This work showed a significant increase in systolic BP of insulin resistant rats by $13.9 \%$. The mechanism of fructoseinduced hypertension is not well understood, but factors as uric acid production, hyperinsulinemia aldehyde formation, and altered vascular reactivity have been implicated. ${ }^{14}$

Also sympathetic activation and changes in endothelium function may be involved in the increase in blood pressure in fructose-fed rats. ${ }^{15}$ It was found that long-term (40 wk) fructose feeding impaired vascular relaxation in the mesenteric arteries of male rats and it was associated with an increased expression of the angiotensin II type 1 receptor in adipose tissue. ${ }^{14,16}$

Potential explanations for the increase in blood pressure that accompany insulin resistance and hyperinsulinemia are: 1) increase in sympathetic neural outflow and plasma catecholamine concentrations associated with increased plasma insulin concentrations 2) insulin action at the level of the proximal tubule to increase fluid reabsorption. ${ }^{14}$

The present work showed a significant increase in triglyceride (TG), cholesterol and LDL blood levels by $23.2 \%, 3 \%$ and $5.6 \%$ respectively insulin resistant rats with a significant decline by $5.9 \%$ in HDL level in agreement with others who demonstrated that both plasma and liver levels of cholesterol and LDL were high with low level of HDL in rats fed fructose saying that exposure of the liver to large quantities of fructose leads to rapid stimulation of Lipogenesis that contributes to TG accumulation and that in the liver more fructose than glucose was converted to TG and secretion of TG into the serum was higher after fructose administration. ${ }^{17}$

Also, the increased TG levels in fructose-fed rats might be attributed both to the overproduction of hepatic VLDL-TG and impaired peripheral clearance. Increased hepatic TG production might result from the conversion of fructose carbon into glycerol-3-phosphate, a precursor of lipid synthesis or from increased esterification of circulatory nonesterified fatty acids. ${ }^{14,17}$

Studies had found evidence for enhanced lipoprotein assembly, reduced intracellular apolipoprotein B degradation, increased expression of microsomal triacylglycerol transfer protein and secretion of apolipoprotein-B-containing lipoprotein particles in a fructose-fed insulin-resistant animal model. ${ }^{17}$

Also hyper-triglyceridemia could be explained by assuming that fructose facilitates oxidative damage in tissues leading to increased plasma phospholipids and their depletion in tissues of fructose-fed rats. The major targets of damaging free radicals are the cellular and membrane phospholipids. The oxidative tissue damage can release the membrane lipids such as free fatty acids (FFA) and phospholipids into blood. ${ }^{16}$

Fructose feeding can also lead to a decrease in the ability of insulin to stimulate the activity of lipoprotein lipase (LPL). This reduction in the activity of LPL; can be ascribed to the insulin resistance induced by fructose. Besides, it could be possible that the activity of hepatic lipase, that hydrolyses triglycerides and phospholipids from lipoprotein, is blocked in these rats. ${ }^{16}$

In addition this work showed a significant rise of both blood glucose and insulin levels by $115.4 \%$ and $232.8 \%$ respectively in insulin resistant rats, in accordance with studies showing that chronic feeding with fructose-enriched diets produces hyperinsulinaemia and insulin resistance and that body, heart weight, non-fasting blood glucose and plasma insulin were marginally increased in fructose fed rats compared to controls. ${ }^{14,17,18}$ It was also reported that fructose feeding reduces insulin sensitivity, induces development of hepatic insulin resistance/glucose intolerance and dyslipidemia. $^{17}$

The increase in BW as a result of increased insulin secretion and reduced leptin production is accompanied by an increase in circulating non-esterified fatty acids. The exposure to increased concentrations of nonesterified fatty acids may reduce insulin sensitivity by increasing the intramyocellular lipid content. ${ }^{14,18,19}$ 


\section{Effect of induction of insulin resistance on lipolytic} activity of adipose tissue in rats:

In this work the lipolytic activity of $\mathrm{SC}$ and visceral adipose tissue, showed a significant increase in presence of adrenaline by $55.2 \%$ and $78.6 \%$ respectively in insulin resistant rats.

Matching others who found that administration of a high fructose-diet in rats increases the release of FFA from adipose tissue in vitro, concluding that the enhanced FFA release is due to a reduced re-esterification of FFA in adipose tissue rather than to an enhanced lipolysis. The reduced re-esterification of FFA in fructose-fed rats is probably connected with the reduced glucose utilization in adipose tissue. ${ }^{17,20}$ Isolated adipocytes were used to study the effect of administration of a high-fructose-diet on the morphological aspects and metabolic function of the subcutaneous and visceral adipose tissue. It showed an increase in fat cell size accompanied by moderate increase of basal lipolysis and a decrease of the antilipolytic action of insulin in both types of adipocytes, being more evident in visceral adipose tissue. ${ }^{21}$

Adipose tissue metabolism is influenced by the size of the constituent cells in both rats and humans. Studies observed an increase of triglyceride stores within the fat pad in longterm fructose-fed rats. LPL was significantly higher in this tissue which promotes the rate of lipolysis. Additionally, studies demonstrated an enhancement in the activities of several key enzymes related to lipolytic pathway in the epididymal tissue of rats fed fructose diet for 12 months. Another explanation was related to changes in adipose tissue fatty acid synthetase (FAS) activity which paralleled changes in plasma triacylglycerol concentrations. Both were increased by fructose feeding. ${ }^{20,22}$

Studies done on rats showed that fructose feeding increases FAS activity and lipogenesis in the liver, in adipose tissue, however, lipogenesis was inversely correlated with hepatic lipogenesis. i.e., lower FAS activity in the fructose fed rats. These results suggest that the regulation of FAS mRNA or activity in adipose tissue may depend on substrate availability rather than on plasma hormonal concentrations. ${ }^{17,23}$

Data in the present work revealed a higher lipolytic activity in visceral $(375.1 \pm 20.14 \mathrm{mg} / \mathrm{dl})$ compared to SC adipose tissue $(274.2 \pm 40.09 \mathrm{mg} / \mathrm{dl})$ in fructose fed rats. Previous studies suggested that stimulated lipolysis in visceral adipose tissue in vitro was greater in adipocytes of fructose fed rats. Others found in diabetes type 2, adverse changes in lipoprotein particle number and size strongly related to accumulation of visceral fat which is considered to have greater lipolytic activity and has favored access to the liver through the portal vein. Besides, it also suggested that subcutaneous body fat having lower lipolytic activity compared with central fat, may serve as a metabolic sink by taking up excess circulating FFA and even preventing ectopic fat accumulation. ${ }^{24,25}$

Our results also revealed a great decline in the antilipolytic activity of insulin in fructose-fed rats. In response to insulin, SC and visceral adipose lipolytic activity showed a significant increase by $109.3 \%$ and $167 \%$ respectively, matching other study that showed a diminished sensitivity to insulin and increased fatty acid release from adipocytes of Wistar rats fed a fructose-rich diet for 3-4 wk. ${ }^{25}$ Also, an increase of adipocyte lipolysis and lack of its response to insulin has been observed in humans fed a sucrose diet predominantly in visceral adipose tissue. ${ }^{26}$

Studies showed that insulin and catecholamines play an important role in controlling the activity of hormone sensitive lipase (HSL), suggesting that the hyperinsulinemia induced by fructose feeding does not down-regulate HSL activity but significantly increased the lipolytic activity from the adipocytes of rats fed this diet. Studies also reported that chronic elevation of plasma FFA mainly due to both an increase of basal lipolysis and a substantial reduction of antilipolytic action of insulin in fructose fed rats could contribute to and/or worsen the impaired insulin sensitivity and whole body glucose uptake and utilization. ${ }^{26-28}$

\section{Conclusion:}

The present work showed that 3 month of dietary fructose regimen is sufficient to induce insulin resistance with a significant increase in body weight, systolic blood pressure, blood TG, Cholesterol, LDL, glucose, Insulin levels and a significant decrease in HDL level. This state of insulin resistance is accompanied by increase in lipolytic activity of both subcutaneous and visceral adipose tissue, being higher in visceral adipose tissue.

\section{Conflict of interest: none}

\section{References:}

1. Sunehag AG, Toffolo G, Campioni M, et al.; Effects of dietary macronutrient intake on insulin sensitivity and secretion and glucose and lipid metabolism in healthy, obese adolescents; J Clin Endocrinol Metabol 2005;90:4496-502.

2. Gaby AR. Adverse effects of dietary fructose. Alternat Med Rev 2005;10:294-306.

3. Jürgens H, Haass W, Castaneda TR, et al. Consuming fructose sweetened beverages increases body adiposity in mice. Obes Res 2005;13:1146-56. 
4. Stanhope KL, Schwarz JM, Keim NL, et al. Consuming fructose sweetened, not glucose-sweetened, beverages increases visceral adiposity and lipids and decreases insulin sensitivity in over mass/ obese humans. J Clin Invest 2009;119:1322-34.

5. McGuinness OP, Cherrington AD. Effects of fructose on hepatic glucose metabolism. Curr Opin Clin Nutr Metab Care 2003;6:441-8.

6. Wajchenberg BL. Subcutaneous and visceral adipose tissue: their relation to the metabolic syndrome. Endocrine Reviews 2000;2:697-738.

7. Rodbell M. Metabolism of isolated fat cells. The journal of chemistry 1964;230:375-80.

8. Rodbell M, Birnbaumer L, Stephen LP, et al. The Glucagon-sensitive Adenyl Cyclase System in Plasma Membranes of Rat Liver. J Biol Chem 1971;246:187782.

9. Henry RJ. Clinical Chemistry Principles and Techniques, 2nd ed. New York: Harper \& Row, 1974:664-6.

10. Burtis CA and Ashwood ER. Tietz textbook of clinical chemistry, 3rd ed. Philadelphia: WB Saunders, 1999:265-309.

11. Alsaifa M, Mansour S, Duwaihyb B. Influence of dietary fat quantity and composition on glucose tolerance and insulin sensitivity in rats. Metabolism 2004;24:417-25.

12. Duplus E, Glorian M, Foresti C. Fatty Acid Regulation of Gene Transcription; J Biol Chem 2000;275:3074952.

13. Alexandra S, Wei M., Carlos AR, et al. FructoseInduced Leptin Resistance Exacerbates Weight Gain in Response to Subsequent High Fat Feeding; Am J Physiol Regul Integr Comp 2008;295:1370-5.

14. Elliott S, Keim N, Stern J, et al. Fructose, weight gain, and the insulin resistance syndrome. Am J Clin Nutr 2002;76:911-22.

15. Valensi P. Hypertension, single sugars and fatty acids. J Hum Hypertens 2005;19:S5-S9.

16. Takagawa Y, Berger ME, Hori MT, et al. Long-term fructose feeding impairs vascular relaxation in rat mesenteric arteries. Am J Hypertens 2001;14:811-7.

17. Basciano H, Federico L, Adeli K. Fructose, insulin resistance, and metabolic dyslipidemia. Nutr Metab (Lond) 2005;21:21-5.
18. Howarth FC, Qureshi A, Al-Mansoori D, et al. Contraction and intracellular $\mathrm{Ca} 2+$ in ventricular myocytes from rats receiving fructose-enriched diets. Int J Diabetes \& Metabolism 2003;11:62-6.

19. Abdulla MA, Sattar MA, Johns EJ. The Relation between Fructose-Induced Metabolic Syndrome and Altered Renal Haemodynamic and Excretory Function in the Rat. Intl J Nephrol 2011; Article ID 934659 doi: $10.4061 / 2011 / 934659$

20. Alzamendi A, Giovambattista A, Raschia A, et al. Fructose-rich diet-induced abdominal adipose tissue endocrine dysfunction in normal male rats. Endocrine 2009;35:227-32

21. Busetto L. visceral obesity and the metabolic syndrome: Effects of weight loss. Nutr Metab Cardiovasc Dis 2001;11:195-204.

22. Soria A, D'Alessandro ME, Yolanda B, et al. Duration of feeding on a sucrose-rich diet determines metabolic and morphological changes in rat adipocytes. J Appl Physiol 2001;91:2109-16.

23. Lc Tappy, Kim-Anne Lê. Metabolic Effects of Fructose and the Worldwide Increase in Obesity. Physiol Rev; 2010;90:23-46.

24. Wajchenberg BL. Subcutaneous and visceral adipose tissue: their relation to the metabolic syndrome Endocr Rev 2000;21:697-738.

25. Vrána A, Fábry P, Slabochová Z, et al. Effect of dietary fructose on free fatty acid release from adipose tissue and serum free fatty acid concentration in the rat. Nutr Metab 1974;17:74-83.

26. Buthelezi $P$, van der Merwe $M$, Lönnroth $N$, et al. Ethnic Differences in the Responsiveness of Adipocyte Lipolytic Activity to Insulin. Obes Res 2000;8:171-8.

27. Wang SP, Laurin N, Himms-Hagen J, et al. The adipose tissue phenotype of hormone-sensitive lipase deficiency in mice. Obes Res 2001;9:119-28.

28. Sztalryd C, Kraemer FB. Differences in hormonesensitive lipase expression in white adipose tissue from various anatomic locations of the rat. Metabolism 1994;43:241-7. 